\title{
Sin, Punishment and Redemption in King Lear
}

\author{
Yujun Liu \\ School of Foreign Languages, Qingdao University of Science and Technology \\ Box 502, 69 Songling Road, Qingdao 266061, China \\ E-mail: lyjlotus@126.com
}

Financed by Qingdao University of Science and Technology. Project number: 08XA05

\begin{abstract}
Holy Bible is the classic of Christian, having a deep and far-reaching influence on the thought and the everyday life of western people. The elements in Holy Bible were shown everywhere in Shakespeare's tragedy: King Lear. This article aims to explore the essential propositions of Christian: sin, punishment and redemption as the clue, and analyzes the behaviors and fates of characters in King Lear.

First, human beings are born with sins. The characters can not escape the deep-rooted original sin in human's nature, committing different kinds of sins. Second, God is fair to everyone. The punishment follows their sins. The characters deserved their proper punishment accordingly. Owing to their different sins, some experienced kinds of sufferings; some lost their life; some will be tortured in the hell forever. Third, God punishes those who commit the sins, but he also saves those who die for justice, and forgives those who repent. Suffering is the road leading to being redempted. After those sufferings, people were saved.
\end{abstract}

The religious ideas are widely used King Lear, further heightening the feelings of Christians, and preaching the lessons of punishing the evil and advocating the good.

Keywords: Bible, Sin, Punishment, Redemption

\section{Introduction}

William Shakespeare lived during the time of English Renaissance featuring humanism. And he is regarded as one of the most prominent representatives of this time. And a lot of books and papers studying humanistic elements have been cropping up all the time. However, Shakespeare and his works are also influenced by Christianity notably. Superficially, these two points of views seem to be in contradiction with each other. Virtually, humanism and Christianity are not a completely opposite Cultural system. The movement of Renaissance denied many aspects of Christianity, but the fact that the movement of Renaissance is deeply rooted in the hotbed of Christian Culture can not be ignored either. Therefore many spirits and ideas of Renaissance are the extension and development of inherent elements of Christianity under the new historical circumstances. So now it should be not difficult for us to accept the certain influence of religion on Shakespeare and his works.

From 1601 to 1605, William Shakespeare created his four principal tragedies, Hamlet, Othello, King Lear, and Macbeth. For four hundred years, these tragedies have been sparkling with a peculiar beauty of their own, and have never failed to evoke pity or fear. How come they have achieved such everlasting effects? The reason is that Shakespeare endows them, especially King Lear, with some valuable religious qualities, which this thesis paper attempts to examine.

\section{The influence of Christianity on Shakespeare and his works}

\subsection{The influence of Christianity on Shakespeare}

Scholars and critics of all strips have long conceded the importance of religious belief in the production of art, literature and drama. Yet how Christian was Shakespeare? This remains a disputing question for a long time. And it is still very disputing till today. The eminent critic Harold Bloom, author of the best-selling Shakespeare: The invention of the Human (Riverhead Books, 1999), argues that "Shakespeare seems too wise to believe anything" political or religious. According to Bloom, Shakespeare could not have any religious convictions and still remain Shakespeare. And Rev. Paul Murry, O.P., notes: "It would not, I think, to be helpful to characterize Shakespeare formally as a religious dramatist. 
The fact is that he chose, by and large, to leave religion alone.’[1] As to Bloom's view, I myself am strongly opposed to it. Compared with the former, the latter sounds more reasonable. During the English Renaissance, Protestant reformers had recently put an end to the centuries-old tradition of religious drama. And strict laws regulating theater prohibited any explicit religious or current political events from being represented on stage. So no playwright writing for the public during this time could be formally considered a religious dramatist. Therefore, Shakespeare had to choose to address the religious issues in a strictly universal way, free of any clannish meaning or color.

Although all the above-mentioned, he is very Catholic in many respects. And it is not exaggerated to say that Shakespeare is a Catholic totally. And there is a lot of evidences demonstrating that Shakespeare is closely related to Catholic.

First, Shakespeare's families are closely connected with Christian. Both of his parents appeared to have conformed to Christian despite the risks to personal wealth, freedom and life. His mother, Mary Arden, came from one of the most prominent and tenacious Catholic families in Warwickshire. The head of the clan, Edward Arden, for instance, kept his own Catholic priest, disguised as a gardener but known throughout the Avon valley as Father Hugh Hall. One of Arden's sons-in-law, a hot-headed Catholic Fantastic named John Somerville, traveled to London on a personal mission to assassinate the Queen; apparently quite deranged, he betrayed his intensions to anyone who would listen to his ranting during his frequent tavern-hopping,. Inevitably, he was arrested and, under torture, implicated Arden and Hall. The priest died in prison while his case was being adjudicated; but in 1583 the hapless Arden was hanged and quartered, and his head struck on a spike on London Bridge.

William Shakespeare was nineteen years old at the time of his cousin's execution. Well before that traumatic date, from as far back as William's thirteenth year, his father John had apparently begun to run into financial difficulties, at which time he tried to avoid town meetings and church attendance, allegedly to elude summons by subpoena (one could be served for debt in church). Presumably the debts were real (he defaulted on a mortgage in 1580), but the father's financial woes seem to have been exacerbated by Crown revenge against the Ardens. In any event, John's name was later entered on the recusant rolls of Stratford for failing to come to Anglican Church services on Sunday, as the law required. One often reads that John Shakespeare's absence was due strictly to his fear of subpoena. But Catholic convictions must have played at least some role in the father's recusancy. A document, supposed to have been found about 1750 under the tiles of a house in Stratford which had once been John Shakespeare's, professes to be the spiritual testament of the said John Shakespeare, and assuming it to be authentic it would clearly prove him to have been a Catholic. The document, which was at first unhesitatingly accepted as genuine by Malone, is considered by most modern Shakespeare scholars to be a fabrication of J. Jordan who sent it to Malone. (Chuck Lee, 1908: 302)

And we know that William Shakespeare's daughter was also fined for recusancy and that William and his fiancée Anne Hathway married not in his Stratford church but in Temple Grafton, five miles from his birthplace. Neither the Shakespeare nor the Hathways had connections there, but the vicar of the village, John Frith, was cited in contemporary records as "unsound in religion," a code-term for Catholic priests. And finally, a seventeenth-century Anglican archdeacon from nearby Coventry reported that, according to Stratford oral tradition, Shakespeare "died a papist".

Besides his family members, many of his teachers, classmates and friends maintained close connections with the Christian. Shakespeare's teachers at the Stratford grammar school all had contacts with the "old faith". Simon Hunt, his first schoolmaster, from 1571 to 1575 , left Stratford to matriculate at the University of Doual in the summer of 1575 and later become a Jesuit. One of Shakespeare's classmates from Stratford, Robert Dibdale, abruptly left with Hunt, was also ordained a priest, and was martyred in 1586. And while studying for the priesthood Debdale shared classes with Thomas Cottom (executed in 1582), whose brother John Cottom was a schoolmaster at Stratford and taught Shakespeare until, under mounting Anti-Catholic pressure from the Crown, he fled home to Lancashire, a Catholic stronghold. And just at the recommendation of Cottom Shakespeare took up a position as a tutor and a player in the Houghton household, a recusant noble Catholic family of Lancashire.( David Bradley, 1979: 28) All these go to show that the dramatist in his youth must have been brought up in a very Catholic atmosphere, and indeed the history of the Gunpowder Plot conspirators shows that the neighborhood was regarded as quite a hotbed of recusancy.

\subsection{The influence of Holy Bible on Shakespeare's Works}

Due to Shakespeare's close connection with Christianity, the classical work of Christianity, Holy Bible, deeply influenced all of Shakespeare's works. We all know that Shakespeare knew Holy Bible thoroughly, not only a by-stander, but also a propagator. And there were a lot of pistils in the Bible he read. And especially when he read The Divine Comedy, he circled all the words and expressions related to Holy Bible, without any omission. His tragedies, comedies, historical plays, poems, etc. are full of the elements of Holy Bible. And among all of Shakespeare's works, the religious ideas embodied more fully in his tragedies than his other works, especially in his four famous tragedies Hamlet, Macbeth, King Lear and Othello. The English contemporary critic, Helen Cardina, even deemed Shakespeare's tragedies as "Christian tragedies".(Helen Gardner, 1998: 72-74) And one of the famous English scholars has said that there will be no Shakespeare's work without the Holy Bible.(Zhu Weiji, 1992: 64) 
As the essential Christian propositions: sin, punishment, and redemption are found everywhere in his four tragedies. And these are important themes which form the inherent plots and advocated the tragedies; or they become the main measures to realize the tragedies and enlarge the connotations of the tragedies. And here in this article I will mainly explore the exhibition of Sin, Punishment and Redemption in King Lear.

\section{Sin, punishment and redemption embodied in King Lear}

\subsection{The sin}

What is the sin? The ceaselessly swollen desires and lusts will result in the sin; too much free will result in the sin; harboring the evil idea will result in the sin; violating the law of any moral or ethical rules will result in the sin; and so on . The bible emphasizes the original sin of the man. Humans are born with sin. Man's original sin begins with our forefathers Adam and Eve. Before the original sin comes into our world, "Everyone who commits sin is a child of the evil; for the devil has been sinning from the beginning." (National TSPM\&CCC, 2000: 422) And our forefathers Adam and Eve have the right to choose to be good or to be evil, but this depends on their attitudes. Under the seduction of the evil serpent, Eve ate the forbidden fruit in the Eden and gave some to her husband. So they committed the original sin and were driven out of Eden by God as the punishment. Therefore, from now on, every man is born with sin.

Sin can be found in every works of Shakespeare. The connotation of $\sin$ in four tragedies is deeper and more serious than his comedies. The four tragedies do not just take some kind of sinful behaviors as the plot frame, but go into the deep meaning of the sin such as the apprehension and the application of the original sin.

\subsubsection{The sin in King Lear}

"Everyone who commits sin is a child of the evil; for evil has been sinning from the beginning." (National TSPM\&CCC, 2000: 422 ) Goneril, Regan and Edmund are devils if they were not human. Goneril and Regan persecuted their old father, drove him out of their house, and left him homeless in the wilderness. They would be wiling to kill each other to be Edmund's queen. They are selfish. Their blood is cold. Edmund demands that all of his desires must be satisfied. His insatiable ambition extends past Cornwall to English Throne. He claimed, "All with me's meet that I can fashion fit." Besides, Edmund disrespected the God. He said, "My father compounded with my mother under the Dragon's tail and my nativity was under Ursa Major, so that it follows I am rough and lecherous. Fut, I should have been that I am, had the maidenliest star in the firmanment twinkled on my bastardizing." (William Shakespeare, 1999: 435) And all these demonstrate the original sin in human.

Regarding Lear, he is an imperious, capricious, arrogant and self-centered king. In any case, he welcomes poisoned flattery but interprets well-intended criticism, whether from Cordelia or Kent, as treason. Lear's ego seems fully capable ofdemanding the sacrifice from his daughters, especially from his favorite, Cordelia; he has given them his whole kingdom, now let them care for him as befits, his royal rank and patriarchal role. Goneril and Regan are content to flatter and promise obedience knowing that they will turn him out once he has relinquished his authority. Cordelia senses that Lear is demanding love as payment for his parental kindliness. Genuine love ought rather to be selfless. She refuses to lie like her sisters. So Lear misjudges his children and disinherits his loving daughter in favor of his duplicitous daughters.

And Gloucester is another Lear. Without any clear evidence he wronged his virtuous son and fell into prey to Edmund's deceptions and disinherits him.

There are too many subjective ideas in these two old man's mind. This is also one nature of human resulting from the original sin.

\subsection{The Punishment}

Since everyone is sinned from the beginning according to the Bible. The punishment must follow behind. Usually, there are three aspects of meaning in the punishment: the punishment in the present life, the punishment of the whole life and the punishment of conscience. Adam and Eve are driven out of Eden by God and have to suffer on the earth. And Cain is driven out of hometown. All these convey a meaning that one must responsible for what he is doing in his real life.

"Just as sin came into the world through one man, death came through sin and so death spread to all because all have sinned." (National TSPM\&CCC, 2000: 270) And death is the most serious punishment. God has arranged for the man. There are also three kinds of death according to the Bible. The first one is the death of the body, or the departure of the body and the soul. To the pagans, this kind of death means that he will lost all the nice things in the earth and be tortured in the hell forever. To the well-behaved believers, this kind of death means free from the bitter life, entering a beautiful world and enjoying the happiness forever. The second one is the death of the soul, that is, the restorable departure of the soul and God. And just like the first kind of death, it is possible to resurrect from this kind of death. For example, the souls of two criminals who are crucified with Jesus have departed from God. Their souls are dead. But one of the criminals begins to have faith in Jesus before he dies. When the other criminals kept deriding Jesus, he said, "Do you not fear God, since you are under the same sentence of condemnation? And we indeed have been condemned justly, 
for we are getting what we deserve for our deeds, but this man has done nothing wrong." Jesus told him, "Truly I tell you, today you will be with me in the paradise." (National TSPM\&CCC, 2000: 157) The third kind of death is the eternal death, which means the complete departure with God and the torture in the hell forever. The death of the criminal who kept deriding Jesus when he was going to put to death belongs to this type. He will never have the chance to resurrect from his eternal death.

\subsubsection{The punishment in King Lear}

In King Lear, none of the people who sinned can avoid the punishment of God. Regan is poisoned to death by her sister Goneril. And Goneril commits suicide. Goneril and Regan have done too many evil things. But they have not repented and asked for pardon until their death. Just like the criminal who deriding Jesus even when he will put to death very soon, their deaths belong to the eternal death. They will be tortured in the hell forever. And they will never have any chance to resurrect from their death. Edmund, whose soul is dead before his body dies, have done numerous evil deeds. He is killed by his brother and deserved his punishment.

Regarding Lear and Gloucester, they experienced the hardship owing to their errors. Lear was turned out into the storm by his two daughters and went mad; Gloucester is made physically blinded because of his son Edmund's betrayal.

\subsection{The Redemption}

Man has sinned from the beginning. And man's original sin will no doubt lead to the punishment from the law on the earth, God and the conscience. But it does not mean that man can not find a way out. The Bible will lead the man to redemption. The God will pardon their sins if they believe God. And man can be rescued through the repentance of their sins and their conversion to God. And God loves all those who regret for guilt.

Besides, hardship is the symbol of purgatory. One can also be rescued through the hardship he experienced, and his soul will be purified. After the suffering, one may realize the truth thoroughly. And in Shakespeare's four tragedies, each hero finally realizes his misdeeds and obtains a deeper understanding of life.

Christian is a religion of love. The Christian spirit of benevolence, leniency and universal love goes through the Bible distinctively. So some people can be rescued by God because of their benevolence, leniency and universal love. These are the moral qualities the Bible advocates. Therefore the soul this kind of people will be rescued by god even their body is dead. They will live happily in the heaven with God. [21]

\subsubsection{The redemption in King Lear}

In King Lear, Lear and Gloucester are rescued through the suffering they have experienced. Lear's suffering is not without compensation. He learned the truth and discovered himself through his suffering. And through his suffering, he has understood what human's suffering and need are all about. He begins to pray for the poor, "Poor naked wretches, wheresoe'er you are,/ That bide the pelting of this pitiless storm,/ How shall your houseless heads and unfed sides,/ Your looped and windowed raggedness, defend you / From seasons such as these? O, I have ta'en/ Too little care of this1 Take physic, pomp;/ Expose thyself to feel what wretches feel, / That thou mayest shake the superflux to them/ And show the heavens more just."[22]And he begins to sympathize with the fool, "Come on, my boy. How dost, my boy? Art cold? / I am cold myself. - Where is the straw, my fellow? / The art of our necessities is strange, /And can make vile things precious. Come, your hovel.- / Poor fool and knave, I have one part in my heart/ That's sorry yet for thee.(William Shakespeare, 1999: 483) And when Lear recognized Cordelia after all of his suffering, he attempted to kneel down before her and said, "I am a very old foolish fond old man." and "I fear I am not in my perfect mind." To kneel down is a kind of true enlightenment, indicting the repentance in the bottom of his heart.

Gloucester learns a similar truth and expresses it in much the same way as Lear. Like Lear he has driven into exile a virtuous child and had placed in the power of the wicked. Enlightenment comes only though suffering. Just as Lear achieves spiritual wisdom when he goes mad, Gloucester achieves spiritual vision when he is physically blinded. His eyes having been ground out by the heel of Cornwall's boot, Gloucester asks for Edmund only to learn that Edmund has betrayed him in return for siding with Lear in the approaching civil war. Gloucester's response, however, is not to accuse Edmund of treachery but to beg forgiveness of the wronged Edgar.

Cordelia and Edgar are rescued by God because of their benevolence, leniency and universal love. They both have forgiven and cherished their sinned fathers. And their love is one of the elements that make their fathers grow spiritually. The power of their love, though learned too late to avert catastrophe is at last discovered in its very defeat. And the love embodies by Cordelia and Edgar's final triumphs over the more anarchic and brutal forces embodies by Regan and Goneril, which can be seen in Albany's shifting and reconciliation and the restoration of the national order and Edgar's survival and restoration to his social status. Although Cordelia is dead, her death is not a secular one. The soul of Jesus in the Holy Bible has returned to the arms of God. Cordelia has died for justice like Jesus, so her death is the same as the death of Jesus. She is remembered and respected by the people and her soul also returns to the arms of God.

Edmund, whose soul is dead before his body dies, have done numerous evil deeds. But just as the criminal who is 
crucified with Jesus together is converted to Jesus before he is put to death, he tells Kent the secret order of killing Lear Cordelia and helps them rescue Cordelia and Lear. Therefore, he will not tortured by the flame in the hell. He will be with the God in the heaven.

\section{Conclusion}

The Christian ideas are the body and soul of Shakespeare's four tragedies, which add the features of western classic culture and the religious elements to the play. Without them the tragedies will be lack of their original vitality.

Shakespeare's King Lear ends with heroes' death--King Lear dies of heartbreak and over-exertion. The sin, punishment and redemption are embodied fully in the death of King Lear. And these tragic endings render the tragedy a far-reaching influence among western countries. The drama not only plays the role of moral teaching of punishing the evil and advocating the good, but also leads the audience to think about means of "punishment" and "death" under the Christian culture. King Lear has deepened the religious ideas in the play, and further heightened the Christian feelings, making the play shed the eternal radiance similar to the Holy Bible.

\section{References}

Chuck Lee. (1908). Life of William Shakespeare. Oxford: Pergamon Press.

David Bradley. (1979). An Introduction to Shakespeare and his Contemporaries. Cambridge: Cambridge University, 1979.28-30.

Helen Gardner. (1998). Religion and Literature. Chengdu: Sichuan People's Publishing House.

National TSPM\&CCC. (2000). The New Testament . Nanjing: Amity Printing Co., LTD.

Paul J. Voss. (2002). How Catholic Was Shakespeare? [DB/OL] [Online] Available: http://www.catholiceducation.org/articles/arts/al0147.html.

William Shakespeare. (1999). King Lear . New York: Bantam Books

Zhu, Weiji. (1992). Christianity and Literature. Shanghai: Shanghai Bookstore. 